\title{
Avian Ecological Diversity as an Indicator of Urban Forest Functionality. Results from Two Case Studies in Northern and Southern Italy.
}

\author{
Giovanni Sanesi, Emilio Padoa-Schioppa, Leonardo Lorusso \\ Luciana Bottoni, and Raffaele Lafortezza
}

\begin{abstract}
Greenspaces and forest trees contribute to a number of environmental functions in urban environments, such as the survival of urban-dwelling species (e.g., bird species). This paper analyzes the relationship between greenspace characteristics (structural and spatial attributes) and the diversity of avian ecology species. This provides research findings coming from two studies conducted in Italy. Using point-count method, a quantification was done of the abundance and diversity of bird species in a number of greenspaces having different structural attributes (e.g., vegetation type, tree height) and spatial characteristics (e.g., location, connectivity). Results showed positive correlations between greenspaces with a more diverse and mature forest vegetation and the number of specimens and species observed in the two studies. A positive correlation appeared also between distance to the city centre and richness and abundance of bird species. Finally, we discuss some of the main implications for enhancing the functional attributes of greenspaces by using avian ecological indicators to inform ecologically sound urban planning and design.

Key Words. Urban Environments; Point-Counts; Urban Biodiversity; Forest Birds; Italy; Ecological Indicators; Urban Greenspaces.
\end{abstract}

Greenspaces and forest areas are essential components of the urban environment because they provide a wide range of environmental and social functions to cities and urban dwellers (Costanza et al. 1997; Orians 1986; Padoa-Schioppa et al. 2007; Sanesi and Chiarello 2006). Increasing levels of urban densification are calling attention to those measures that can mitigate urban island effects (Mazza and Rydin 1997) or compensate for the overload of pollutants in (urban) air and soil (McPherson et al. 1994; Nowak et al. 2006). Citizens are also growing concerned over the the consequence of intense urbanization and its effects on their physical and/or psychological well-being (Van Herzele and Wiedemann 2003; Chiesura 2004; Sanesi et al. 2006). A healthy urban environment is often associated with the availability of large forest areas within cities and the accessibility of such areas by urban residents (e.g., Hartig 2004; Hartig and Cooper-Marcus 2006).

Forest trees are also essential for the survival of many animal and plant species in urban environments. In particular, studies have demonstrated positive effects of forest trees on both invertebrate and vertebrate species, such as spiders (Alaruikka et al. 2002), ants (Yamaguchi 2004), butterflies (Hermy and Cornelis 2000), carabides (Niemelä et al. 2002; Ishitani et al. 2003; Magura et al. 2005), and passerines (Wiens 1989; Keast 1990; Petty and Avery 1990; Mörtberg and Wallentinus 2000; Padoa-Schioppa et al. 2006; Ferrara et al. 2008). For example, Watts and Larivière (2004) showed how the presence of carabides in the urban environment could be explained by the size of green areas and the presence of indigenous forest species.

Highly dense urban areas with a lack of greenspaces and forest trees are often associated with the presence of generalist species nesting in hollow trees (Emlen 1974; Lancaster and Rees 1979; Beissinger 1982).

Although the influence of urban forests on species has been the focus of recent studies (Blair 1996), few contributions have explored the subject by considering the biological response of species to different types and structures of forest vegetation in urban environments. In this direction, this paper aims to explore the relationship between the urban forest structure and the abundance of certain bird species. We provide research findings coming from two studies conducted in Italy at northern (Milan) and southern (Bari) locations. At both locations, bird species were used as indicators of ecological diversity in urban environments (i.e., avian ecological diversity). Using point-count method, we quantified the abundance and diversity of bird species in a number of greenspaces of different structural attributes (e.g., vegetation type, tree height) and spatial characteristics (e.g., location, connectivity). We finally discussed some of the main implications for enhancing the functional attributes by selecting avian ecological indicators and use them to inform ecologically sound urban planning and design.

\section{MATERIALS AND METHODS}

\section{Study Areas}

This study was conducted on sixteen greenspaces located in two main urban environments: Milan, northern Italy (N. 13) and Bari, southern Italy (N. 3).

Greenspaces were opportunistically selected by considering the availability of supplementary data and information on forest species composition and structure at the year of their establishment as well as data on past and current forest management practices. Selection was also based on considerations on the extension of each city and the amount of (public) greenspaces available.

As a general figure, Milan (45 $53^{\prime} 71^{\prime \prime N}$; 9 $\left.9^{\circ} 20^{\prime} 97^{\prime \prime} \mathrm{E}\right)$ extends to approximately $182 \mathrm{~km}^{2}\left(72.20 \mathrm{mi}^{2}\right)$ with a population of 1,303,602 inhabitants (ISTAT, 2005). This figure rises up to $3,900,000$ inhabitants when including surrounding towns and vil- 
lages. Overall, greenspaces in Milan covers a surface of $15.20 \mathrm{~km}^{2}$ $\left(5.86 \mathrm{mi}^{2}\right)$; the average amount of greenspaces per capita is approximately $11.60 \mathrm{~m}^{2}\left(124.86 \mathrm{ft}^{2}\right.$; Agenzia Mobilità e Ambiente, 2002).

Bari $\left(41^{\circ} 73^{\prime \prime} \mathrm{N} ; 8^{\circ} 32^{\prime} 55^{\prime \prime} \mathrm{E}\right)$ extends to approximately $116.20 \mathrm{~km}^{2}\left(44.87 \mathrm{mi}^{2}\right)$ with a population 316,000 inhabitants. Public greenspaces cover a surface of $1.13 \mathrm{~km}^{2}\left(0.44 \mathrm{mi}^{2}\right)$ with $3.4 \mathrm{~m}^{2}\left(36.60 \mathrm{ft}^{2}\right)$ of greenspaces per capita (ISTAT, 2005).

\section{Bird Species Survey}

In each greenspace, we collected a number of data related to the richness and abundance of bird species. From March 2005 to July 2006, birds were observed and recorded during the breeding season by means of point-counts with unlimited distance (Bibby et al. 2000). "Point-counts" are a common method for sampling bird species (Bani et al. 2006) because it allows an extensive surveying of sample areas and the surrounding landscape (Blondel et al. 1970; Reynolds 1990). In addition, this method enables collecting a wide range of ecological data on species with a cost-effective balance (Selmi and Boulinier 2003).

In the study, birds were surveyed placing each sample within a grid of $250 \mathrm{~m} \times 250 \mathrm{~m}$ while avoiding the overlapping of two continuous observations. Overall, 80 point-counts were covered during field campaigns. Among bird species surveyed in the two locations, two species were assumed as potential indicators of urban forest functionality: great tit (Parus major Linnaeus 1758) and the serin (Serinus serinus Linnaeus 1766). Both species were found in the two locations in more than 50 point-counts. Furthermore, great tit and serin are within the 15 target species described by the "atlas of birds" of Milan (Avium, 2006).

Species abundance for the two indicator species was expressed in terms of number of individuals per point-count (Bibby et al. 2000).

\section{DATA ANALYSIS}

As first step, we performed a cluster analysis using UPGMA method (Unweighted Pair Group Method using arithmetic Averages) which allowed comparing birds in terms of species composition over the sixteen greenspaces (Spellerberg et al. 1999).

In addition, we analyzed the structural and spatial characteristics of the sixteen urban greenspaces, such as: dimension in hectares, percentage of vegetation cover, and distance from the core center of the city (identified by the center of the polygonal area representing the city - see Table 1 ). These data were analyzed using a nonparametric test: "R-Spearman Coefficient" (due to the non-normal distribution of observations). Linear regression models were used to predict species richness on the basis of greenspaces' characteristics.

We measured the DBH [Diameter Breast Height, taken at 1.3 $\mathrm{m}(4.27 \mathrm{ft})$ above ground] of the closest 100 trees surrounding each point-count within a radius of $100 \mathrm{~m}(328 \mathrm{ft})$. DBH values were then analyzed in relation to species abundance values considering the following intervals of DBH: minimum, first quartile, median, third quartile, and maximum. Such intervals were used to derive input data for an additional regression model. For each DBH interval, we compared the observed species abundance with the average abundance across the 80 point-counts and used those observations with higher values to construct an "optimal" model of the DBH distribution. All the other observations were instrumental for creating a "minimal" model of this distribution. The "U-Mann-Whitney Test" was used for the scope. This approach
Table 1. Synthetic park's features. Forest cover (the area covered by trees) correlation was not evaluated in Lama Balice park, because the natural vegetation was populated with shrubs and not trees.

\begin{tabular}{lllll}
\hline $\begin{array}{l}\text { Urban forest } \\
\text { area }\end{array}$ & $\begin{array}{l}\text { Area } \\
\text { (ha) }\end{array}$ & Code & $\begin{array}{l}\text { Distance from } \\
\text { the city }\end{array}$ & $\begin{array}{l}\text { Forest } \\
\text { cover } \\
\text { (ha) }\end{array}$ \\
\hline $\begin{array}{l}\text { Milano Parco Nord } \\
\text { Milano Trenno }\end{array}$ & MI1 & 596,5 & 7168 & 80,117 \\
Milano Bosco in città & MI3 & 61 & 6895 & 46,71 \\
Milano Sempione & MI4 & 51,2 & 8800 & 38,628 \\
Milano Monte stella & MI5 & 38,6 & 5256 & 26,912 \\
Milano Montanelli & MI6 & 19,4 & 1424 & 15,858 \\
Parco Ravizza & MI7 & 7,8 & 1812 & 10,54 \\
Milano Cave & MI8 & 119,1 & 7032 & 3,284 \\
Parco Solari & MI9 & 5,6 & 1951 & 37,042 \\
Milano Forlanini & MI10 & 59,7 & 5572 & 2,122 \\
Giardini Via Pallavicino & MI1 & 6,2 & 2396 & 31,834 \\
Milano Lambro & MI12 & 71,7 & 5774 & 2,352 \\
Parco Trotter di Turro & MI13 & 13,1 & 4306 & 38,539 \\
Bari Umberto 1 & BA1 & 1,8 & 0,1 & 6,967 \\
Bari 2 giugno & BA2 & 4 & 2000 & 0,27 \\
Bari Lama Balice & BA3 & 119 & 7500 & 1 \\
\hline
\end{tabular}

has been used in previous studies (Massa et al. 2003a) and it follows the assumptions that: an high level of abundance is generally preferable for birds in urban settings (Bock and Jones 2004); that birds select forest with high values of $\mathrm{DBH}$, mature urban forest; and that species in urban environments are likely to occur within heterogeneous and uneven-aged forest vegetation (Blair 1996; Donnelly and Marzluff 2006; Sandström et al. 2006).

\section{RESULTS}

Table 2 illustrates bird species diversity for each of the analyzed urban greenspaces. In total, 56 species were recorded: 53 species in Milan and 11 in Bari; and 4,393 specimens were indentified: 3,587 in Milan and 649 in Bari.

The large part of these species are typical of forest-type habitat (Keast 1990; Hinsley et al. 1995; Massa et al. 2003b; Bani et al. 2006), such as: "wren" (Troglodytes troglodytes L.); "wryneck" (Jynx torquilla L.); "short-toed treecreeper" (Certhia brachydactyla C.L.Brehm 1820); "golden oriole" (Oriolus oriolus L.); "jay" (Garrulus glandarius L.); and "great spotted woodpecker" (Dendrocopos major L.). Other species are common in farm-

Table 2. Number of bird species identified and number of specimens detected in each greenspace.

\begin{tabular}{llll}
\hline Green spaces & Code & N of species & N $^{\circ}$ of specimens \\
\hline Milano Parco Nord & MI1 & 38 & 1378 \\
Milano Trenno & MI2 & 18 & 193 \\
Milano Bosco in città & MI3 & 32 & 244 \\
Milano Sempione & MI4 & 19 & 397 \\
Milano Monte stella & MI5 & 19 & 206 \\
Milano Montanelli & MI6 & 12 & 75 \\
Parco Ravizza & MI7 & 6 & 40 \\
Milano Cave & MI8 & 34 & 379 \\
Parco Solari & MI9 & 12 & 78 \\
Milano Forlanini & MI10 & 22 & 276 \\
Giardini Via Pallavicino & MI1 & 10 & 39 \\
Milano Lambro & MI2 & 26 & 227 \\
Parco Trotter di Turro & MI13 & 8 & 55 \\
Bari Umberto 1 & BA1 & 8 & 402 \\
Bari 2 giugno & BA2 & 11 & 125 \\
Bari Lama Balice & BA3 & 16 & 122
\end{tabular}


lands and hedgerows (Chamberlain and Fuller 2001; Gregory et al. 2001; Padoa-Schioppa 2006), such as: "stonechat" (Saxicola torquata Linnaeus 1766); "red-backed strike" (Lanius collirio L.); "melodius warbler" (Hippolais poliglotta L.). Most of the remaining species are without specific requirements in terms of habitat and could be defined as generalist species (Hagemeijer and Blair 1997; Tomialojć, 1998; Jedicke 2000; Massa et al. 2004), such as: "feral pigeon." (Columba livia, Gmelin, 1789); "hooded crow" (Corvus corone cornix, L.); "starling" (Sturnus vulgaris, L.); "italian sparrow" (Passer domesticus X italiane, L.).

Water-bird species were also identified because of the presence of ponds and artificial lakes in some of the analyzed greenspaces (e.g., Parco delle Cave in Milan): little grebe (Tachybaptus ruficollis); great crested grebe (Podices cristatus); and little bittern (Ixobrychus minutus). All these species have an interest in terms of habitat conservation in urban and periurban environments (Massa et al. 2004).

Through the UPGMA Cluster Analysis, we classified the 16 greenspaces into 3 main clusters or groups (Figure 1), such as: (1) the three largest greenspaces of Milan (Parco Nord, Parco delle Cave, Bosco in Città); (2) the three greenspaces in Bari (Lama Balice, Parco 2 Giugno, Giardini di Piazza Umberto); and (3) the remaining 10 greenspaces in Milan (Milano Trenno, Milano Sempione, Milano Monte Stella, Milano Montanelli, Parco Ravizza, Parco Solari, Milano Forlanini, Giardini Via Pallavicino, Milano Lambro). These clusters of greenspaces (inter-group) showed similar characteristics inside the group (intra-group).

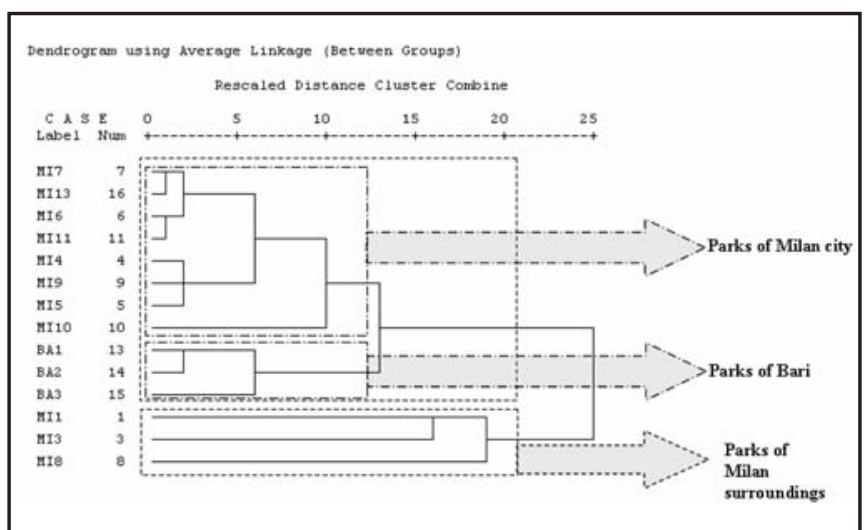

Figure 1. Cluster analysis. See Table 1 for greenspaces' names.

Figure 2 illustrates the results of the regression analysis which considered the main characteristics of urban greenspaces as independent variables, and species richness as dependent variable (expressed as number of bird species). A high correlation emerged between "species richness" and "distance from the city" and between "species richness" and "amount of forest tree cover." These findings are consistent with other studies, e.g., Gilbert (1989), Jokimäki (1999), Hostetler and Holling (2000), Melles et al. (2003), Blair (2004).

Figure 3 (Mann-Whitney U-test) illustrates the levels of abundance for the two indicator species (great tit and serin), based on DBH values (minimum, first quarter, median, third quarter and maximum). In the case of "serin," when $\mathrm{DBH}_{\min }>8 \mathrm{~cm} ; \mathrm{DBH}_{1 \mathrm{st}}$ quarter $>20 \mathrm{~cm} ; \mathrm{DBH}_{\text {median }}>30 \mathrm{~cm} ; \mathrm{DBH}_{3 \mathrm{rd} \mathrm{quarter}}>40 \mathrm{~cm}$, species abundance gets significantly higher than the one measured at lower level of DBH (see: Mann-Whitnay U-test, in Figure 3). In the case of the "great tit," $\mathrm{DBH}_{\text {max }}$ was the only interval providing significant results. The resulting regression curve for the "great tit" revealed a positive correlation between $\mathrm{DBH}$ and species abundance: the higher the tree diameter the higher the abundance of the species. This could be explained by the habitat preference of the great tit for large trees (Cowie and Hinsley 1988). The regression curves predicting the mimimal and optimal distribution of DBH for great tit and serin are reported in Figure 4. Such equations could be used to design an "ideal" structural model of forest stands in urban environments supporting avian species diversity.
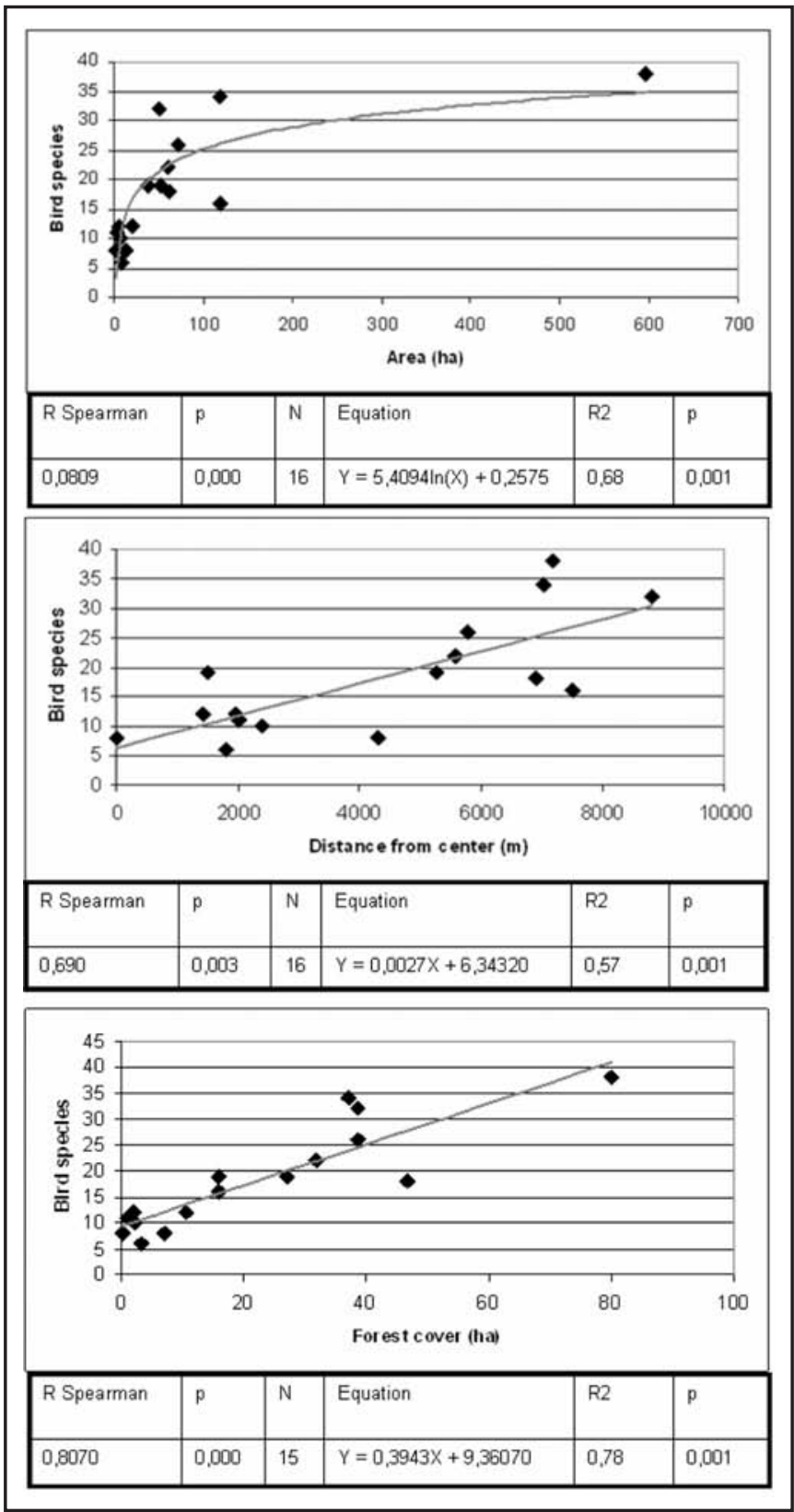

Figure 2. Spearman correlation coefficient and regression analysis for number of species and area of the greenspace. Forest cover is the area covered by trees. 


\section{DISCUSSION AND CONCLUSIONS}

In urban settings, bird species are important indicators of environmental quality and ecological functionality. At urban scale, the study of bird species in relation to greenspaces characteristics is essential to better understand the current status of urban forest resources and related functions as well as to monitor progresses towards urban sustainability.

In this study, we provided evidence on the response of bird species to certain structural attributes of greenspaces, such as the presence of mature and heterogeneous forest stands (high level of DBH). Among the analyzed greenspaces, Parco Nord (Milan) provided the most encouraging results in terms of species richness. Such results could be explained by: the large extension covered by this greenspace (approximately 600 ha), the high percentage of mature forest trees, and the relevant distance to city center (Sanesi et al. 2007).

Besides these characteristics, it is important to consider the spatial connectivity of greenspaces with the surrounding landscape components, especially forest patches, open spaces, grasslands and mixed-croplands with presence of hedgerows (Sodhi et al. 1999; Farina 2006). For example, Giardino di via Pallavicino, Parco Solari and Giardino di via Ravizza in Milan although having approximately the same extension (16 ha) revealed a contrasting patterns in terms of species richness (see Table 3). This could be explained by the fact that Giardino di via Pallavicino and Parco Solari belong to a system of parks and other greenspaces (public and private lands) which constitutes a kind of ecological network supporting bird species dispersal.

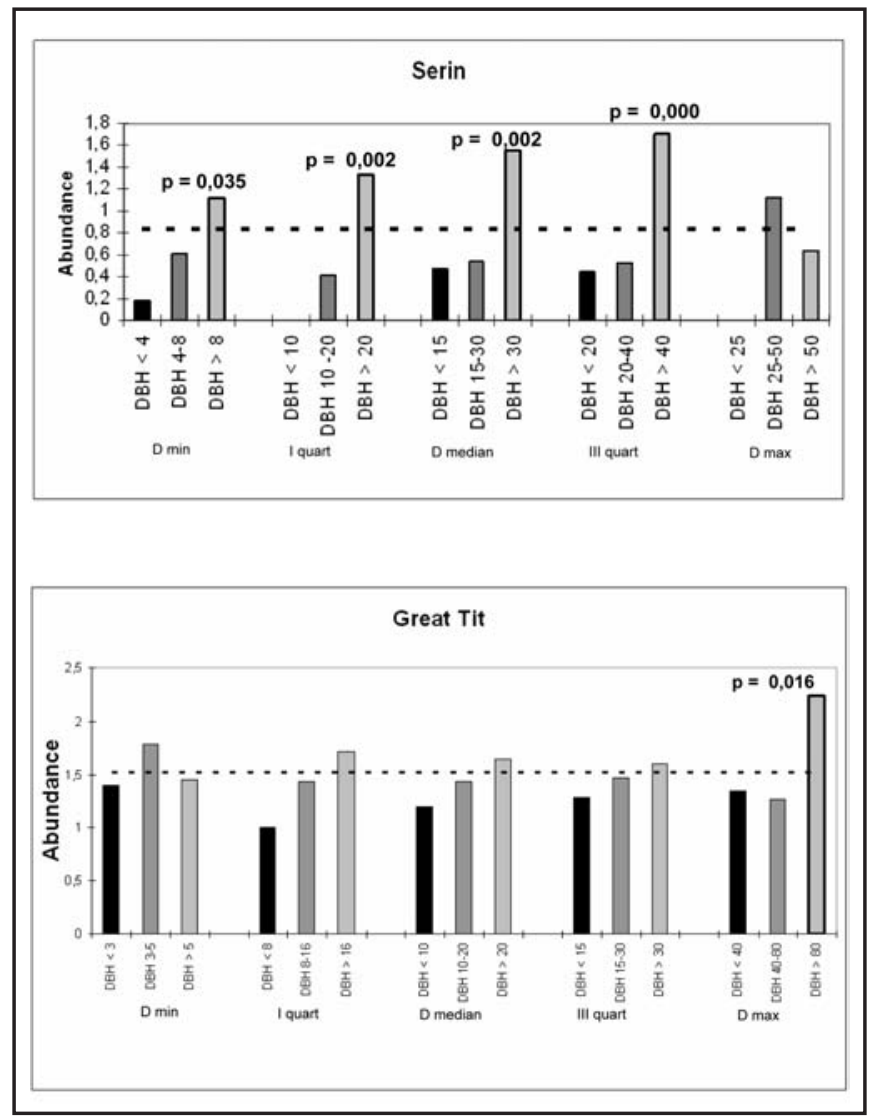

Figure 3. Tree structure and abundance of serin and great tit.
In synthesis, this study provided the following caveats:

1) The dimension of greenspaces and the amount of tree cover are critical factors supporting avian ecological diversity in urban environments. As a consequence, urban forest planners and managers should promote the planning and design of large greenspaces within cities and the connection of greenspaces with the surrounding landscape elements.

2) The structural heterogeneity of forest trees within greenspaces (explained by the DBH analysis) is a fundamental aspect supporting high level of species abundance of birds.

3) The conservation of species diversity in urban areas should be based on the knowledge on one or more indicators species having different habitat requirements in terms of vegetation and trees' structure (as explained by Ficetola et al. 2007).

The results of our work suggests that following the approach of ecosystem services and the "Biophilia hypothesis" (Costanza et al. 1997; Wilson 1984) a greenspace in urban areas should be managed for both social needs and conservation purposes.

Acknowledgments. The research was financed by Ministry of the Instruction of the University and the Research inside Program of Research of Interest National (PRIN-2004).

The research was coordinated by Giovanni Sanesi; data analysis and experimental design was performed by Emilio Padoa-Schioppa;

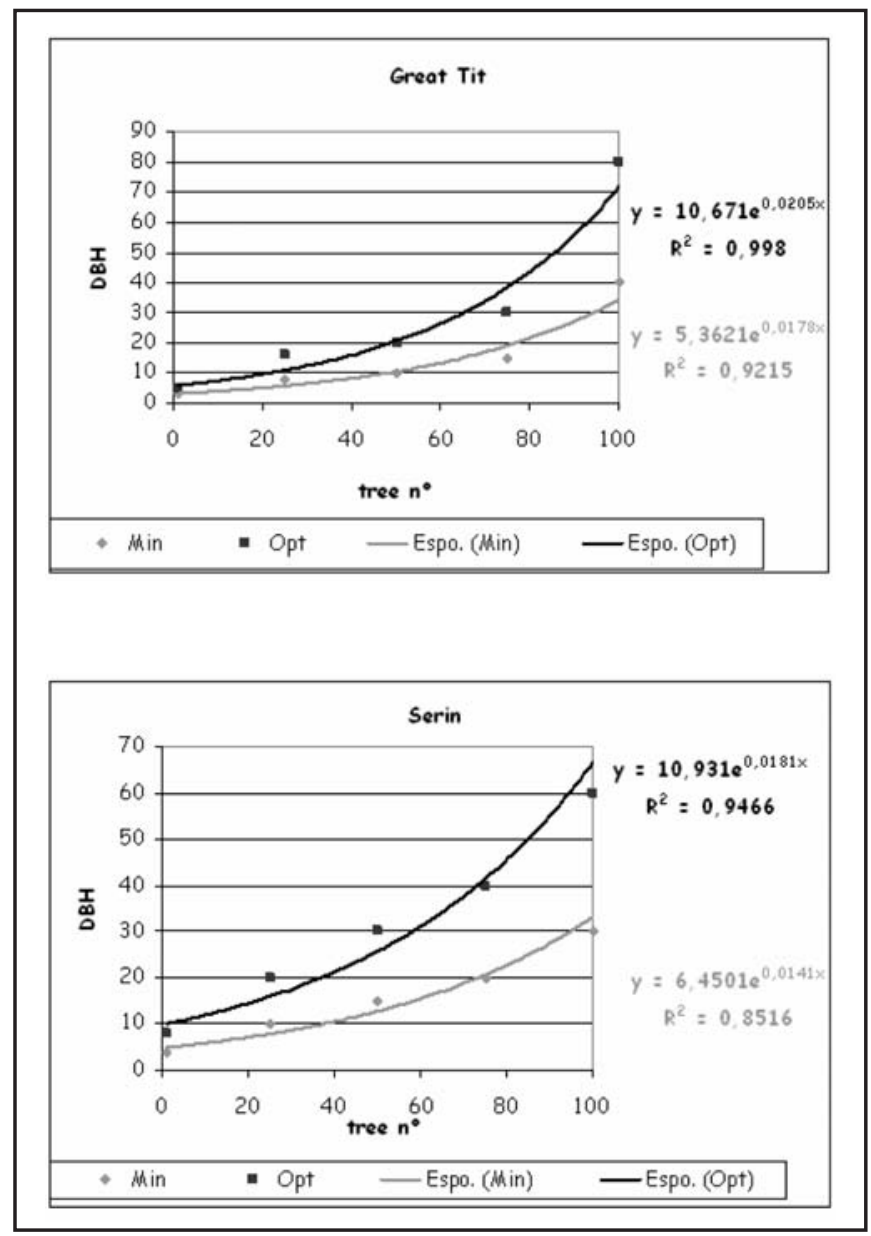

Figure 4. Regression equations for tree. 
Leonardo Lorusso and Raffaele Lafortezza were responsible for Bari and Luciana Bottoni and Emilio Padoa-Schioppa for Milano.

\section{LITERATURE CITED}

Agenzia Mobilità e Ambiente. 2002. Rapporto annuale 2001 sulla mobilità urbana. Comune di Milano.

Alaruikka, D., D.J. Kotze, K. Matveinen, and J. Niemelä. 2002. Carabid beetle and spider assemblages along a forested urban-rural gradient in southern Finland. Kluwer Academic Publishers. Journal of Insect Conservation 6: 195-206.

Avium. 2006. Atlante virtuale degli uccelli di Milano. www.avium.it.

Bani, L., D. Massimino, L. Bottoni, and R. Massa. 2006. A multi-scale method for selecting indicator species and priority conservation areas: a case study for broadleaved forests in Lombardy, Italy. Conservation Biology 20(2):512-526.

Beissinger, S.R., and D.R. Osborne. 1982. Effects of urbanization on avian community organization. The Condor 84(1):75-83.

Bibby, C.J., N.D. Burgess, and D.A. Hill. 2000. Bird Census Techniques. Academic Press, London, 2nd edition.

Blair, R.B. 1996. Land use and avian species diversity along an urban gradient. Ecological Applications 6(2):506-519.

Blair, R.B. 2004. The Effects of Urban Sprawl on Birds at Multiple Levels of Biological Organization Ecology and Society 9(5):art.2.

Blondel, J., C. Ferry, and B. Frochot. 1970. La méthode des indices ponctuels d'abondance (I.P.A.) on des releves davifaune par 'stations decoutè'. Alauda 38:55-71.

Bock, C.E., and Z.F. Jones. 2004. Avian habitat evaluation: should counting birds count? Frontiers in Ecology and Environment 2(8):403410 .

Chamberlain, D.E., and J. Fuller. 2001. Contrasting patterns of change in the distribution and abundance of farmland birds in relation to farming system in lowland Britain. Global Ecology and Biogeography 10:399-409.

Chiesura, A., 2004. The role of urban parks for the sustainable city. Landscape and Urban Planning 68(1):129-138.

Costanza, R., R. d'Arge, R. de Groot, S. Farber, M. Grasso, B. Hannon, B. Limburg, S. Naeem R. O’Neil, J. Paruelo, R.G. Raskin, P. Sutton, and M. van den Belt. 1997 The value of the world's ecosystem services and natural capital. Nature 387: 253-260.

Cowie, R.J., and S.A. Hinsley. 1988. Feeding ecology of great tits (Parus major) and blue tits (Parus caeruleus), breeding in suburban gardens. The Journal of Animal Ecology, 57(2):611-626.

Donnelly, R., and J.M. Marzluff. 2006. Relative importance of habitat quantity, structure, and spatial pattern to birds in urbanizing environments. Urban Ecosystems 9:2, 99

Emlen, J.T. 1974. An urban bird community in Tucson, AZ: Derivation, structure and regulation. Condor 76:184-197.

Farina, A. 2006. Principles and Methods in Landscape Ecology. Springer, $412 \mathrm{pp}$.

Ferrara, G., G. Tellini Florenzano, E. Tarasco, O. Triggiani, L. Lorusso, R. Lafortezza, and G. Sanesi. 2008. L'avifauna come indicatore di biodiversità in ambito urbano: applicazione in aree verdi della città di Bari. Italia Forestale e Montana. (in press; in Italian, abstract in English)

Ficetola, G.F., R. Sacchi, S. Scali, A. Gentilli, F. De Bernardi, and P. Galeotti. 2007. Vertebrates respond differently to human disturbance: implications for the use of a focal species approach. Acta Oecologica 31, 109-118.

Gilbert, OL. 1989. The Ecology of Urban Habitats. Chapman \& Hall. 380 pp.
Gregory, R.D., D.G. Noble, P.A. Cranswick, L.H. Campbell, M.M. Rehfisch, and S.R. Baillie. 2001. The state of the UK's birds 2000. RSPB, BTO and WWT.

Hagemeijer, E.J.M., and M.J. Blair (Eds.). 1997. The EBCC Atlas of European Breending Birds: Their Distribution and Abundance. T \& A D Poyser, London.

Hartig, T., 2004. Restorative environments. In Spielberger, C. (Ed.), Encyclopedia of Applied Psychology, Academic Press, San Diego, USA, Vol.3, pp.273-278.

Hartig, T., and C. Cooper-Marcus. 2006. Healing gardens - Places for nature in healthcare. The Lancet, 368, S36-S37.

Hermy, M., and J. Cornelis. 2000. Towards a monitoring method and a number of multifaceted and hierarchical biodiversity indicators for urban and suburban parks. Land. and Urb. Planning 49:149-162.

Hinsley, S.A., P.E. Bellamy, I. Newton, and T.H. Sparks. 1995. Habitat and landscape factors influencing the presence of individual breeding bird species in woodland fragments. Journal of Avian Biology 26:94-104.

Hostetler, M.E., and C.S. Holling. 2000. Detecting the scales at which birds respond to structure in urban landscapes. Urban Ecosys. 4:25-54.

Ishitani, M., D.J. Kotze, and J. Niemelä. 2003. Changes in carabid beetle assemblages across an urban-rural gradient in Japan. Ecography 26: 481-489.

ISTAT. 2005. Indicatori ambientali urbani 2002-2003. Istituto Nazionale di Statistica. (in Italian).

Jedicke, J. 2000. Stadt- und Dorfökosysteme: Umweltfaktoren, Siedlungsbindung von Vogelarten, Avizönosen, Verstädterungsprozesse und Naturchutz -ein Überblick Vogelwelt. 121:67-86 (in German, abstract in English).

Jokimäki, J. 1999. Occurrence of breeding bird species in urban parks: effects of park structure and broad-scale variables. Urban Ecosystems 3:21-34.

Keast, A. 1990. Biogeography and Ecology of Forest Bird Communities. SPB Academic. 416 pp.

Lancaster, R.K., and W.E. Rees. 1979. Bird communities and the structure of urban habitats. Can. J. Zool. 57:2358-2368.

Magura, T., B. Tóthmérész, and T. Molnár. 2005. Species richness of carabids along a forested urban-rural gradient in eastern Hungary. European Carabidology 2003, Proceedings of the 11th European Carabidologist Meeting.

Massa, R., L. Bani, D. Massimino, and L. Bottoni. 2003a. Foreste e biodiversità faunistica in Lombardia. La biodiversità delle foreste valutata per mezzo delle comunità degli uccelli. Collana "C'è vita nel bosco." Edizioni Regione Lombardia - Agricoltura, 123 pp. (in Italian).

Massa, R., L. Bani, M. Baietto, L. Bottoni, and E. Padoa-Schioppa. 2003b. An Ecological Network for the Milano Region Based on Focal Species. In: Jongman, R.H.G., and G. Pungetti (Eds.). Ecological Networks and Greenways. Chapter 11:188-199. Cambridge University Press, UK.

Massa, R., M. Baietto, L. Bani, L. Bottoni, and E. Padoa-Schioppa. 2004. Distribuzione e status dei vertebrati terrestri della Provincia di Milano. In: S. Giussani (red.). Rete ecologica e fauna terrestre. Studi e progetti. Quaderni della Provincia di Milano, Piano Territoriale $n^{\circ} 23$. Edizioni Angelo Guerini e Associati, Milano.

Mazza, L., and Y. Rydin. 1997. Urban sustainability: discourses, networks and policy tools. Prog. Plann. 47:1-74.

McPherson, E.G., D.J. Nowak, and R.A. Rowntree. 1994. Chicago's Urban Forest Ecosystem: Results of the Chicago Urban Forest Climate Project. United States Department of Agriculture Forest Service Northeastern Forest Experiment Station General Technical Report N E- 186 . 
Melles, S., S. Glenn, and K. Martin. 2003. Urban bird diversity and landscape complexity: species-environment associations along a multiscale habitat gradient. Conservation Ecology 7(1):art.5.

Mörtberg, U., and H.G. Wallentinus. 2000. Red-listed forest bird species in an urban environment - assessment for greenspace corridors. Land. and Urb. Planning 50:215-226.

Niemelä, J., J.D. Kotze, S. Venn, L. Penev, I. Stoyanov, J. Spence, D. Hartley, and E. Montes de Oca. 2002. Carabid beetle assemblages (Coleoptera, Carabidae) across urban-rural gradients: an international comparison. Landscape Ecology 17:387-401.

Nowak, D.J., D.E. Crane, and J.C. Stevens. 2006. Air pollution removal by urban trees and shrubs in the United States. Urban Forestry \& Urban Greening 3-4:115-123.

Orians, G.H. 1986. An ecological and evolutionary approach to landscape aesthetic, in Penning-Roswell E. C., Lowenthal, D. (Eds.). Meaning and values in landscape, Allen and Unwin, London.

Padoa-Schioppa, E., M. Baietto, R. Massa, and L. Bottoni. 2006. Bird communities as bioindicators: the focal species concept in agricultural landscapes. Ecological Indicators 6:83-93.

Padoa-Schioppa, E., P. Digiovinazzo, and L. Bottoni. 2007. Restoration of multifunctional forests in north west suburban area of Milan: scenario and proposal. In Bunce, R.G.H., Jongman, R.H.G., Hojas, L. and S. Weel (Eds.): 25 years Landscape Ecology: Scientific Principles in Practice. IALE world congress 2007. 08-12 July 2007. Vol. 1. 274 pp.

Petty, S.J., and M.I. Avery. 1990. Forest Bird Communities. Forestry Commission Occasional Paper 26. Forestry Commission, Edinburgh.

Reynolds, R.T., J.M. Scott, and R.A. Nussbaum. 1990. A variable circular-plot method for estimating bird numbers. Condor 82: 309-313.

Sandström, U.G., P. Angelstam, and G. Mikusinski. 2006. Ecological diversity of birds in relation to the structure of urban greenspace. Land. and Urb. Planning 77:39-53.

Sanesi, G., and F. Chiarello. 2006. Residents and urban greenspaces: The case of Bari. Urban Forestry \& Urban Greening 4:125-134.

Sanesi, G., R. Lafortezza, M. Bonnes, and G. Carrus. 2006. Comparison of two different approaches for assessing the psychological and social dimensions of greenspaces. Urban Forestry \& Urban Greening 5:121-129.

Sanesi, G.; R. Lafortezza, P.A. Marziliano, A. Ragazzi, and L. Mariani. 2007. Assessing the current status of urban forest resources in the context of "Parco Nord," Milan, Italy. Landscape and Ecological Engineering, 3(2): 187-198.

Selmi, S., and T. Boulinier. 2003. Does time of season influence bird species number determined from point-count data? A capture-recapture approach. Journal of Field Ornithology 74:349-356.

Sodhi, N.S., C. Briffett, L. Kong, and B. Yuen. 1999. Bird use of linear areas of a tropical city: implications for park connector design and management. Land. and Urb. Planning 45(2-3):123-130.

Spellerberg, I.F., T. Whitten, and J.W.D. Sawyer. 1999. An Introduction to Applied Biogeography. Cambridge University Press. 272 pp.
Tomialojć, L. 1998. Breeding bird densities in some urban versus nonurban habitats: the Dijon case. Acta Ornithol. 33:159-171.

Van Herzele, A., and T.Wiedemann. 2003. A monitoring tool for the provision of accessible and attractive urban greenspaces. Land. and Urb. Planning, 63(2):109-126.

Watts, C. H., and M.-C. Lariviere. 2004. The importance of urban reserves for conserving beetle communities: a case study from New Zealand. Journal of Insect Conservation 8: 47-58.

Wiens, J. A. 1989. The ecology of bird communities. Vol. 2. Processes and variations. Cambridge University Press, Cambridge, United Kingdom.

Wilson, E.O. 1984. Biophilia Harvard University Press.

Yamaguchi, T. 2004. Influence of urbanization on ant distribution in parks of Tokyo and Chiba City, Japan. I. Analysis of ant species richness. Ecological Research 19:209-216.

Giovanni Sanesi

Università degli Studi di Bari

Dipartimento di Scienze delle Produzioni Vegetali via amendola 165/a-70126

Bari, Italy

Emilio Padoa-Schioppa (Corresponding Author)

Università degli Studi di Milano-Bicocca

Dipartimento di Scienze dell'Ambiente e del Territorio

Research Unit of Landscape Ecology

piazza della Scienza 1-20126

Milano, Italy

emilio.padoaschioppa@unimib.it

Raffaele Lafortezza

Università degli Studi di Bari

Dipartimento di Scienze delle Produzioni Vegetali

via amendola 165/a-70126

Bari, Italy

\section{Leonardo Lorusso}

Università degli Studi di Bari

Dipartimento di Scienze delle Produzioni Vegetali

via amendola 165/a-70126

Bari, Italy

Luciana Bottoni

Università degli Studi di Milano-Bicocca

Dipartimento di Scienze dell'Ambiente e del Territorio

Research Unit of Landscape Ecology

piazza della Scienza 1-20126

Milano, Italy 
Résumé. Les espaces verts ainsi que les arbres forestiers, de par leurs fonctions environnementales, contribuent à l'environnement urbain telles qu'à la survie d'espèces dans l'habitat urbain (ex.: espèces d'oiseaux). Cet article analyse la relation entre caractéristiques des espaces verts (attributs structuraux et spatiaux) avec la diversité écologique en espèces aviaires. Ces découvertes de recherche proviennent de deux études menées en Italie. Au moyen de la méthode des points cotés, une quantification a été faite de l'abondance et de la diversité en espèces d'oiseaux au sein d'un certain nombre d'espaces verts qui ont des attributs structuraux (ex.: type de végétation, hauteur des arbres) et spatiaux (ex.: localisation, connectivité) différents. Les résultats montrent des corrélations positives entre les espaces verts avec une végétation forestière plus diversifiée et mature par rapport au nombre de spécimens et d'espèces observées dans les deux études. Une corrélation positive est apparu également entre la distance avec le centre de la ville et la richesse ainsi que l'abondance en espèces d'oiseaux. Finalement, on y discute des applications principales pour améliorer les attributs fonctionnels des espaces verts en utilisant des indicateurs écologiques aviaires pour créer un design et une planification écologique urbaine plus pratique.

Zusammenfassung. Grünzonen und Bäume leisten ihren Beitrag zum Funktionieren einer städtischen Umwelt, zum Beispiel zum Überleben stadtbewohnender Vogelarten. Diese Studie analysiert die Beziehungen zwischen Grünzonen-Charakteristika (strukturelle und räumliche Attribute) und der Vielzahl an Vogelarten. Die vorgestellten Forschungsergebnisse kommen aus zwei Studien, die in Italien durchgeführt wurden. In einer Anzahl von Grünzonen mit verschiedenen strukturellen (z. B. Vegetationstyp, Baumhöhe) und räumlichen Attributen (z. B. Standort, Verbindungen) wurden durch die Punkt-Zähl-Methode eine
Quantifizierung des Vorkommens und der Diversität vorgenommen. Die Ergebnisse zeigen eine positive Korrelation zwischen Grünzonen mit mehr vielfältigem und älterem Baumbestand und der Anzahl an Vögeln und Vogelarten, die in diesen Studien beobachtet wurden. Eine positive Korrelation besteht auch zwischen der Entfernung zum Stadtzentrum und der Vielfalt der Vogelarten. Zum Schluss diskutieren wir einige der wichtigsten Implikationen für die Förderung funktioneller Attribute von Grünzonen durch Einbeziehung von Informationen über Vogelökologie, um zu einer ökologisch sinnvolle Planung und Gestaltung in urbanen Räumen zu kommen.

Resumen. Los bosques y los árboles de los espacios verdes contribuyen a un sinnúmero de funciones ecológicas en ambientes urbanos, tales como la sobrevivencia de especies endémicas (por ej. especies de aves). Este trabajo analiza las relaciones entre características de los espacios verdes (atributos estructurales y espaciales) y la diversidad ecológica de especies aviarias. Esta investigación proviene de dos estudios realizados en Italia. Con el uso del método de conteo puntual se hizo una cuantificación de la abundancia y diversidad de especies de aves en un número de espacios verdes con diferentes atributos estructurales (tipo de vegetación, altura de los árboles) y características espaciales (localidad, conectividad). Los resultados mostraron correlaciones positivas entre los espacios verdes con la vegetación del bosque maduro y el número de especímenes y especies observadas en los dos estudios. Aparece también una correlación positiva entre la distancia al centro de la ciudad y la riqueza y abundancia de especies de aves. Finalmente, discutimos algunas de las principales implicaciones para realzar los atributos funcionales de los espacios verdes, con el uso de indicadores ecológicos aviarios para informar ecológicamente a la planeación y el diseño urbano. 